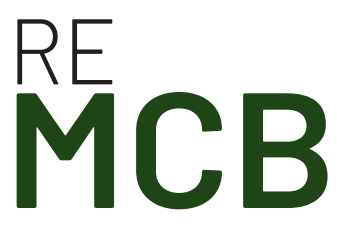

Revista Ecuatoriana de Medicina y Ciencias Biológicas Volumen 42. No. 1, Mayo 2021

\section{First record of Phlegmariurus pruinosus (Herter) B. Øllg. (Lycopodiaceae) for Ecuador from the Cordillera del Cóndor range}

\section{Primer registro de Phlegmariurus pruinosus (Herter) B. Øllg. (Lycopodiaceae) para el Ecuador en la Cordillera del Cóndor}

Álvaro J. Pérez ${ }^{1 *}$, Nicolás Zapata', Daniela Cevallos², Claes Persson³, Edison Rea', Benjamin Øllgaard ${ }^{4}$
'Herbario QCA, Escuela de Ciencias Biológicas, Pontificia Universidad Católica de Ecuador, Av. 12 de

Octubre 1076 y Roca, Apartado 1701-2184, Quito, Ecuador.

${ }^{2}$ Grupo de Investigación en Biodiversidad, Medio Ambiente y Salud (BIOMAS), Universidad de las Américas (UDLA), Vía Nayón s/n,

Quito, Ecuador.

${ }^{3}$ Department of Biological and Environmental Sciences, University of Gothenburg, P.O. Box 461, 40530 Göteborg, Sweden.

${ }^{4}$ Herbarium AAU, Science Museums, and Section for Ecoinformatics and Biodiversity, Department of Biology, Building 1137, University of Aarhus, DK-8000 Aarhus, Denmark.

*Autor de correspondencia: ajperezc@puce.edu.ec

Recibido 1-02-2021

Aceptado 7-04-2021

\section{DOI: $10.26807 /$ remcb.v42i1.887}

e-ISSN 2477-9148

(c) 2021. Este es un artículo publicado en acceso abierto bajo una licencia CC BY 4.0

Como citar este artículo: Pérez AJ, Zapata N, Cevallos D, Persson C, Rea E, Øllgaard B. 2021. First record of Phlegmariurus pruinosus (Herter) B. Øllg. (Lycopodiaceae) for Ecuador from the Cordillera del Cóndor range. Revista Ecuatoriana de Medicina y Ciencias Biológicas 42(1): 57-62. doi: 10.26807/remcb.v42i1.887
Abstract.- During a recent botanical exploration in El Quimi Biological Reserve (Cordillera del Cóndor), Morona-Santiago province, we found for the first time in Ecuador Phlegmariurus pruinosus (Herter) B. Øllg., a species previously recorded as endemic from Peru. We present a morphological description, photographs, and an updated distribution map. Additionally, we highlight the morphological differences with Phlegmariurus campianus (B. Øllg.) B. Øllg., a similar species from Colombia, Ecuador, and Peru. A total of 67 species of Phlegmariurus are recorded for Ecuador..

Keywords: Conservation, Cordillera del Cóndor, Distribution range, El Quimi Biological Reserve, Lycophytes, Morona-Santiago, Taxonomy.

Resumen.- Durante una reciente expedición botánica a la Reserva Biológica El Quimi (Cordillera del Cóndor), provincia de Morona Santiago, registramos por primera vez para el Ecuador a Phlegmariurus pruinosus (Herter) B. Øllg., una especie considerada como endémica del Perú. Se presenta una descripción morfológica, fotografías y un mapa de distribución actualizado. Adicionalmente, se resaltan las diferencias morfológicas con Phlegmariurus campianus (B. Øllg.) B. $\varnothing$ Ølg., una especie similar de Colombia, Ecuador y Perú. Un total de 67 especies de Phlegmariurus están registradas para el Ecuador.

Palabras clave: Conservación, Cordillera del Cóndor, Licofitas, Morona Santiago, Rango de distribución, Reserva Biológica El Quimi, Taxonomía.

\section{Introduction}

The Neotropical clade of Phlegmariurus Holub is the most morphologically and ecologically diverse lineage within the Lycopodiaceae P. Beauv. ex Mirb., comprising approximately 170 species that occupy a broad array of epiphytic and terrestrial habitats (Field et al. 2016). Recent studies suggest that the high diversity of this group is related to the uplift of the Andes mountain range (Wikström and Kenrick 2001, Testo et al. 2018, 2019).

Taxonomic studies of Ecuadorian Lycopodiaceae have registered the occurrence of 85 species (Øllgaard 1988, 2016, 2019), of which Phlegmariurus is the most diverse genus with 67 species, including this new record.

The Cordillera del Cóndor is a poorly explored region that extends ca. $150 \mathrm{~km}$ in a north-south direction from Ecuador to Peru, and is considered a five million year old eastern extension of the Andean chain (Gregory-Wodzicki 2000). Biological exploration in this area has revealed a high concentration of species new to science as well as high endemism, and many species are still to be discovered. This mountain range is isolated from the main Andean range and is geologically distinct, formed with an intermixture of limestone, quartzitic sandstone, and igneous rock of the 
Hollín Formation (Gregory-Wodzicki 2000, Neill 2005). The geology of these mountains is similar to the tepuis of the Guyana shield in northwest South America. In fact, a number of angiosperm genera once thought to be endemic to the tepuis of the Guyana shield have also been found along the Cordillera del Cóndor (Berry et al. 1995, Schulenberg \& Awbrey 1997).

The most recent botanical exploration to El Quimi Reserve took place in January 2019 and was led by scientists from the Herbarium of the Pontifical Catholic University of Ecuador (QCA) with support from the University of Gothenburg Herbarium (GB). This exploration resulted in the first record of Phlegmariurus pruinosus (Herter) B. Øllg., among others (Gradstein et al. 2019, Mashburn et al. 2020, Pérez et al. 2020). This lycophyte species was previously recorded as an endemic, and only known from four localities along central and northern Peru. In this paper, we present a morphological description, photographs and a distribution map for this species. Additionally, we highlight the morphological differences with Phlegmariurus campianus (B. Øllg.) B. Øllg., a morphologically similar species from Colombia, Ecuador and Peru.

\section{Methods}

We made a floristic inventory in the Andean tepui of the El Quimi Biological Reserve during January 2019. The plateau of El Quimi is one of the highest quartzitic sandstone plateaus of the Hollín Formation, which is the geological foundation of the Cordillera del Cóndor in Ecuador. The plateau rises 2000 to $2200 \mathrm{~m}$ elevation and is located in southeastern Morona-Santiago Province, near the Ecuador-Peru border (Gradstein et al. 2019, Mashburn et al. 2020, Pérez et al. 2020).

Collected specimens were deposited in the QCA herbarium. Dry material and pictures of our specimens were the basis to update the morphological description of Phlegmariurus pruinosus (Øllgaard 1994). All measurements were made on dry material, fine observations and measurements of reproductive structures were made with the aid of a dissecting microscope. Major characters were contrasted with a morphologically similar species. The identification was made by consulting pertinent literature, specimens examined at relevant herbaria (AAU, B, MO, QCA, QCNE, S, UC, US) and high-resolution images of the type material of Neotropical taxa (Tropicos database, https://www.tropicos.org/ and the JSTOR Global Plants website http: // plants.jstor.org) and the Pteridoportal website (www.Pteridoportal.org).

\section{Results}

Phlegmariurus pruinosus (Herter) B. Øllg. Phytotaxa 57: 18. 2012

Lycopodium pruinosum Hieron. et Herter ex Herter, Bot. Jahrb. Syst. 43, Beibl. 98: 52. 1909. — Urostachys pruinosus (Herter) Nessel, Arch. Bot. São Paulo 1: 420. 1927. - Huperzia pruinosa (Herter) Holub, Folia Geobot. Phytotax. 20: 76. 1985. - TYPE: Peru, Dept. Amazonas, Prov. Chachapoyas, Tambo Ventillas, 2400-2600 m, 28 Jul. 1904. Weberbauer (err. as Ule in protologue) 4410 (holotype B!, 20 0113758; isotypes BONN, Herb. Nessel 621!, G!, US 1187611!).

Lycopodium durissimum Herter, Bot. Jahrb. Syst. 43, Beibl. 98: 52. 1909. — Urostachys durissimus (Herter) Nessel, Bärlappgewächse 240. 1939. — Huperzia durissima (Herter) Holub, Folia Geobot. Phytotax. 20: 72. 1985. — TYPE: Peru, »Voyage à I'Equateur et au Perou, 1876-77, Guayab.a mars 1877« (err. »Colombia, Guayabal« in protologue), Vidal-Sénèze [Senège] s.n. (holotype P!; isotype BONN, Herb. Nessel 622!).

Plants erect to scandent and distally recurved, unbranched or sparsely branched at base, distally with densely tassel like ramification, at least up to $170 \mathrm{~cm}$ long. Shoots heterophyllous, the basal divisions with expanded leaves ca.10-18 mm in diameter including leaves, distally abruptly constricted to ca. 2-2.5 mm including the reduced, imbricate leaves. Stems excluding leaves up to $5 \mathrm{~mm}$ thick at the base, upward tapering to ca. $0.5-1.5 \mathrm{~cm}$, rigid, dark brown to purplish brown. Expanded leaves of basal divisions borne in alternating, irregular, distant whorls of 4 , the whorls 6-10 mm apart, ascending to spreading or sharply reflexed, lanceolate, straight or recurved, (6-) 8-12 mm long, 2.5-4 mm wide, acute, flat, coriaceous, with smooth, revolute margins, often adaxially concave. Leaves of recurved, constricted divisions subdecussate, densely crowded, sporangiate almost throughout, imbricate, widely ovate with obtuse to acute apex, abaxially 

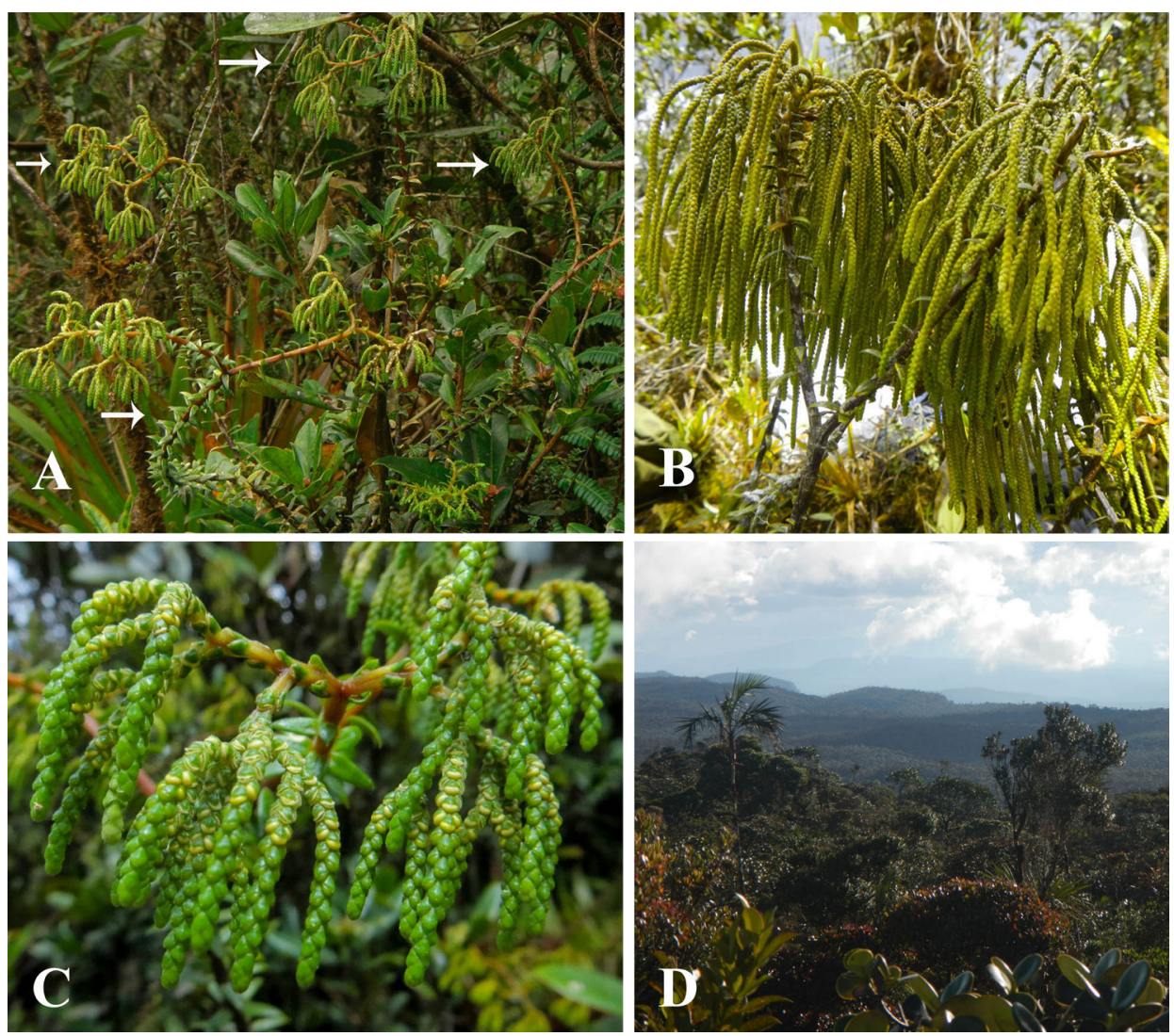

Figura 1. Phlegmariurus pruinosus. A) Habit, arrows shows the stem with vegetative leaves and the terminal sporophylls arrangement. B) Isotomous branching pattern with sporangia at the apex. C) Sporophylls and sporangia detail. D) Habitat in El Quimi Biological Reserve. Photos taken by: A, B, C by Nicolas Zapata, D by Álvaro J. Pérez.

rounded to carinate, 1.2-1.6 mm long and wide, equaling or slightly exceeding the sporangia. Sporangia 1-1.3 $\mathrm{mm}$ wide.

Distribution, habitat and ecology. Until this new record from the Cordillera del Cóndor, in El Quimi Biological Reserve, Morona-Santiago province in Ecuador, this species was considered an endemic and only known from four localities in Peru, the holotype, which was collected in 1904 in Chachapoyas, and from Oxapampa and San Martín (Figure 2). The new locality is a broad plateau with quartzitic sandstones of the Hollín Formation, referred to in recent literature as an Andean tepui (Neill et al. 2014). This is in reference to its similarity with the tepuis of the Guiana Shield (Huber 1995). The habitat is an open tepui-like bromeliad sward and elfin forest at 1900-2200 m (Figure 1D). According to the Ministerio del Ambiente de Ecuador (2013), this locality lies within a much larger zone dominated by evergreen mountain forest of sandstone plains of Cordillera del Cóndor (bosque siempreverde montano sobre mesetas de arenisca de la Cordillera del Cóndor, BsMa01).

Examined specimens. ECUADOR. Morona-Santiago: Gualaquiza Cantón, Parroquia Bomboiza, Reserva Biológica El Quimi, sendero y alrededores entre el campamento Río Cristalino y la

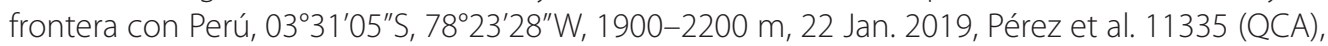
Zapata et al. 524, 525 (QCA); Colecciones en el sendero entre el cerro JJ y el campamento Río

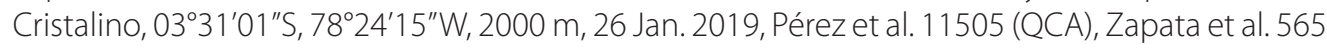
(QCA ), Persson et al. 3245 (GB).

Additional examined specimens. PERU. Amazonas: Chachapoyas, Remnants of forest around 


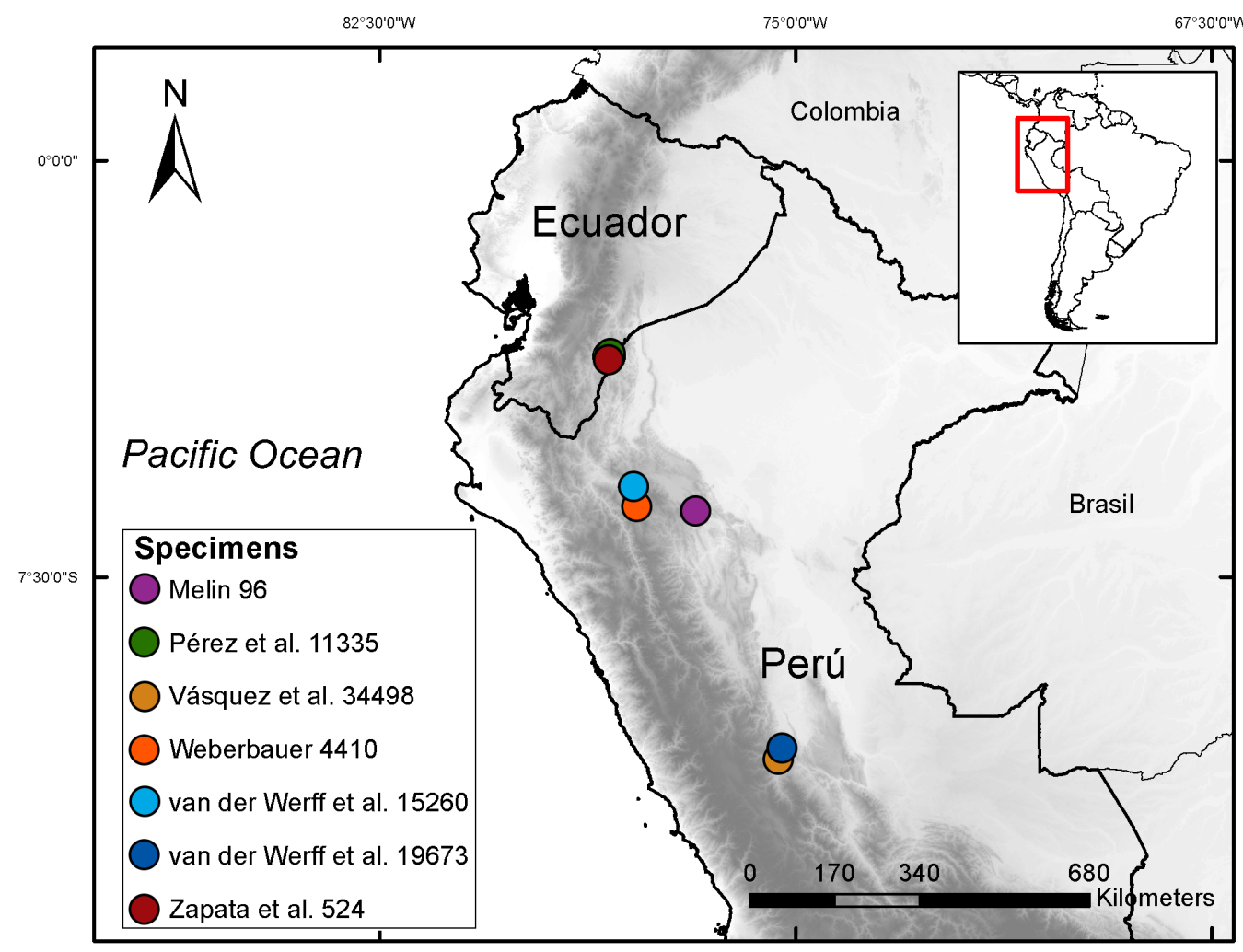

Figure 2. Distribution map of Phlegmariurus pruinosus.

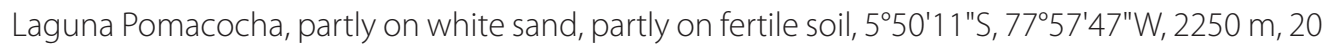
Mar. 1998, van derWerffet al. 15260 (MO 1742421, UC 1728965). Pasco: Oxapampa, From Antenas

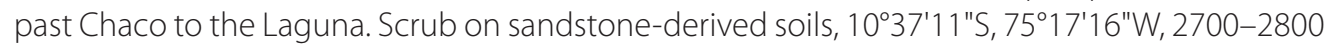
m, 5 May 2005, van der Werff et al. 19673 (MO 1742418, UC 1872823); Zona de Amortiguamiento del Parque Nacional Yanachaga-Chemillen, Sector Chacos, 10³9'20"S, 75¹7'50"W, 2500-2790 m, 10 Oct. 2008, Vásquez et al. 34498 (MO 2646897, UC 2045629). San Martín: Mount Organero, ceja, 1900 m, 14 Aug. 1925, Melin 96 (S 17-13440).

\section{Discussion}

The morphological variation of the Phlegmariurus pruinosus population found in the El Quimi Reserve matches with the description for this species (Øllgaard 1994), except for the size of the plant, that is longer and reach up to $170 \mathrm{~cm}$. Phlegmariurus pruinosus is morphologically similar to Phlegmariurus campianus (B. Øllg.) B. Øllg., a species that occurs from 2400 to $3800 \mathrm{~m}$ of elevation in Colombia, Ecuador and Peru. Phlegmariurus pruinosus can be recognized mainly by its erect to scandent, terrestrial habit (vs. pendulous epiphytes in P. campianus), expanded leaves of proximal divisions in distant, alternating whorls of 4 (vs. expanded leaves of proximal divisions in usually densely crowded, alternating whorls of 3 in P. campianus), the whorls 6-9 $\mathrm{mm}$ apart (vs. the whorls 2,5-5 mm apart in P. campianus) and sporangiate leaves of 1,2-1,6 mm long (vs. sporangiate leaves of 2-3 mm long in P. campianus) (Øllgaard 1994, 2019).

Phlegmariurus pruinosus can be considered a rare species because of its restricted and isolated distribution and the low number of collections available at herbaria, but more exploration effort is needed in order to know the real distribution. Currently, P. pruinosus is known from southern Ecuador along the Cordillera del Cóndor and in central and northern Peru along the eastern foothills of the Andes, growing in cloud forest at 1900-2800 m (Figure 2). In Peru, this species grows in very humid environments and under a thick organic matter covered by bryophytes; while in the new locality, an Andean tepui at the Cordillera del Cóndor in Ecuador, P. pruinosus is more abundant in open areas, dominated by terrestrial bromeliads and scattered shrubs. Here, initially it begins to grow erect and then abducts through the vegetation until it reaches more 
than $150 \mathrm{~cm}$ long, then it emerges as a scandent in the vegetation developing the narrow sporangiate divisions.

We predict that new populations of this species as well as new species to science will be found in future explorations of the plateaus of the Cordillera del Cóndor in Ecuador and Peru. Nevertheless, the biodiversity of this area is severely threatened due to deforestation and mining activities (Mazabanda et al. 2018, Piotrowski \& Ortiz 2019), thus the conservation of this highly biodiverse area is of utmost importance.

\section{Acknowledgements}

Fieldwork was granted by the Ministry of the Environment of Ecuador (003-2019-ICFLO-DNB/ MAE). AJP, NZ, and CP express their gratitude to Patricio Paucar (Director of El Quimi Reserve), Juan Carlos Fernandez (Park ranger of El Quimi Reserve) and the Valle del Quimi community for their support during the fieldwork. To Secretaría de Educación Superior, Ciencia, Tecnología e Innovación de la República del Ecuador for financial support (SENESCYT, Arca de Noé Initiative, S. R. Ron and O. Torres-Carvajal, Principal Investigators). Curators of cited herbaria allowed us to review the material. Finally, we thank the editors and two anonymous reviewers for their valuable suggestions that improved this paper.

\section{Declaration of interest and Authors' Contributions}

All authors declare that there is no conflict of interest. AJP, NZ and CP collected and photographed the plants. BO, NZ and DC identified the specimens. AJP, NZ, DC and ER wrote the text and revised herbarium collections. The field work was funded by the Arca de Noe project and the Herbarium GB.

\section{References}

Berry PE; Huber O, Holst BK. 1995. Phytogeography of the Guayana Region. (Steyermark JA, Berry PE, Holst BK (eds) Flora of the Venezuelan Guayana: volumen 1). Missouri Botanical Garden Press, St. Louis.

Field AR, Testo W, Bostock P, Waycott M. 2016. Molecular phylogenetics and the morphology of the Lycopodiaceae subfamily Huperzioideae supports three genera: Huperzia, Phlegmariurus and Phylloglossum. Molecular Phylogenetics and Evolution 94: 635-657.

Gradstein SR, Reeb C, Persson C, Zapata N, Pérez ÁJ. 2019. Riccardia verticillata Gradst. \& Reeb, a new dendroid species of Riccardia (Aneuraceae) from the Cordillera del Cóndor, Ecuador. Journal of Bryology 41(4): 322-327.

Gregory-Wodzicki KM. 2000. Uplift history of the central and northern Andes: a review. Geological Society of America Bulletin 112: 1091-1105.

Huber O. 1995. Geographical and physical features. In: Berry PE, Holst BK, Yatskievych K, editors. Flora of the Venezuelan Guayana. Vol. 1: Introduction. Missouri Botanical Garden, St. Louis, Missouri. p. 1-62.

Mazabanda C, Kemper R, Thieme A, Hettler B, Finer M. 2018. Impacts of mining project "Mirador" in the Ecuadorian Amazon. [Internet]. [accessed 2021 Mar 31]. https://maaproject.org/miradorecuador/

Mashburn B, Pérez ÁJ, Persson C, Zapata N, Cevallos D, Muchhala N. 2020. Burmeistera quimiensis (Lobelioideae, Campanulaceae): A new species from the Cordillera del Cóndor range in southeast Ecuador. Phytotaxa 433(1): 67-74.

Ministerio del Ambiente del Ecuador. 2013. Sistema de Clasificación de los Ecosistemas del Ecuador Continental. Subsecretaría de Patrimonio Natural, Quito.

Neill DA. 2005. Cordillera del Cóndor: botanical treasures between the Andes and the Amazon. Plant Talk 41: 17-21. 
Neill DA, Rios Paredes M, Torres Montenegro LA, Mori Vargas TJ, Vriesendorp C. 2014. Vegetación y Flora/Negetation and flora. In: Pitman N, Vriesendorp C, Alvira D, Markel JA, Johnston M, Ruelas Inzunza E, Lancha Pizango A, Sarmiento Valenzuela G, Álvarez-Loayza P, Homan J, Wachter T, del Campo Á, Stotz DF, Heilpern S, editors. Peru: Cordillera Escalera-Loreto. Rapid Biological and Social Inventories Report 26. The Field Museum, Chicago. p. 98-119.

Øllgaard B. 1988. Lycopodiaceae. In: Harling G, Andersson L, editors. Flora of Ecuador 33. Gothenburg. p. 1-156.

Øllgaard B. 1994. Family 26: Lycopodiaceae. In: Tryon RM, Stolze RG, editors. Pteridophyta of Peru VI. Fieldiana Botany 34, Chicago. p. 16-66.

Øllgaard B. 2016. Additions, deletions and changes to the Ecuadorian Lycopodiaceae. Phytotaxa 246(2): 93-106.

Øllgaard B. 2019. Synopsis of genus Phlegmariurus (Lycopodiaceae) in Colombia. Phytotaxa 426(1): 1-105.

Pérez ÁJ, Persson C, Zapata N, Mashburn B, Vázquez-García JA. 2020. Magnolia lozanoi (Magnolia subsect. Dugandiodendron, Magnoliaceae) rediscovered on Ecuadorian "tepuis" in Reserva Biológica El Quimi, Cordillera del Cóndor: Critically endangered by open-pit mining. Phytotaxa 428: 255-262.

Piotrowski M, Ortiz E. 2019. Nearing the Tipping Point: Drivers of Deforestation in the Amazon Region. [Internet]. [accessed 2021 Mar 31]. https://www.thedialogue.org/analysis/nearing-thetipping-point-drivers-of-deforestation-in-the-amazon-region/

Schulenberg TS, Awbrey K. 1997. The Cordillera del Cóndor region of Ecuador and Peru: a biological assessment. RAP Working Papers 7. Conservation International, Washington, DC.

Testo W, Øllgaard B, Field A, Almeida T, Kessler M, Barrington DS. 2018. Phylogenetic systematics, morphological evolution, and natural groups in neotropical Phlegmariurus (Lycopodiaceae). Molecular Phylogenetics and Evolution 125: 1-13.

Testo W, Sessa E, Barrington DS. 2019. The rise of the Andes promoted rapid diversification in Neotropical Phlegmariurus (Lycopodiaceae). New Phytologist 222(1): 604-613.

Wikström N, KenrickP. 2001. Evolution of Lycopodiaceae (Lycopsida): Estimating divergence times from $r b c L$ gene sequences by use of nonparametric rate smoothing. Molecular Phylogenetics and Evolution 19: 177-186. 